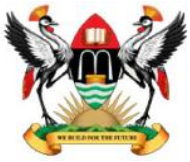

East African School of Higher Education Studies \& Developmen
Makerere Journal of Higher Education

ISSN: 1816-6822; 7 (2) (2015) 49 - 59

DOI: http://dx.doi.org/10.4314/majohe.v7i2.3

(C) The Author(s) 2015

Reprints \& permission: EASHESD

http://ajol.info/majohe

\title{
Academic Staff Development and Output in State Universities in South-South Nigeria
}

\author{
Chukwuma N. Ozurumba ${ }^{1, *}$, Japo Oweikeye Amasuomo ${ }^{1}$ \\ ${ }^{1}$ Niger Delta University [* Corresponding author: ozujumba@gmail.com]
}

\begin{abstract}
This study examines staff development and the output of academic staff in the state universities in South-South Nigeria. An ex-post-facto survey design was used to conduct the research in three state universities in the area. Three research hypotheses were formulated to guide the study. Data were collected from a sample of 402 academic staff. This was done using a questionnaire entitled "Academic Staff Development and Academic Staff Output Questionnaire". One way Analysis of Variance (ANOVA) was used to analyse the data. The findings were that significant relationship exists between staff development and the productivity of academic staff in terms of research, teaching and community service. Therefore, the study concluded that in-service training and attendance of conferences and workshops influence the output of academic staff. Accordingly, it is recommended that adequate funding towards staff development and policies that support staff development are imperative for improved performance.
\end{abstract}

Keywords: Academic staff development; Performance management; Nigeria

\section{$1 \quad$ Introduction}

Education is the key to the development of people and society. It is through education that individuals', groups' and the nations' worth and potentials are realized. This explains why the governments of developing countries provide education for their citizens. Staff are one of the most important components of any educational system, they contribute to the attitudes of the society, thereby shaping the nation (Nkpodia, 2001). The quality of any education system depends on the way the skills of the staff in the system are developed. However, the importance and quality of staff can only be noticed when they are involved in staff development programmes. This is so because staff development focuses on professional growth, bringing about change in individuals' knowledge, understanding, behaviour, attitudes, skills, values and 
beliefs. The purpose of staff development is to further improve job performance, enhance the quality of work environment and foster personal growth and development. Through staff development activities staff acquire knowledge about educational issues and problems, develop and utilize new or improved skills or work ethics and methods, clarify work-related attitudes and values, derive greater satisfaction from work with students, and develop more stimulation and supportive relationships with their colleagues (Boyel, 2004).

On the contrary, it has been observed that most state-owned universities are not adequately productive due to inadequate staff development programmes (Agah, 2002). Academic staff have not lived up to their expectations due to inability of the state government and university administration to expose them to in-service training, conferences, research, community service and current practices in their fields. This has resulted in reduction of quality manpower. Thus, qualified manpower which would have emanated from staff development has decreased tremendously (Okebukola, 2005).

When people talk about increase in productivity, they generally mean increase in output per person. Babalola (2009) explains that to the farmers, increase in productivity might imply a boost in the farming yields, which may be as a result of better and/ or more education and training of farmers. Similarly, increase in productivity of those who are in the construction sector of the economy might be measured in terms of more and/ or better construction of structures. To manufacturers, increase in productivity might imply better or efficient production process and highly-demanded products.

In the service sector like institutions of learning, increase in productivity might be interpreted to mean more and better school leavers and graduates who are morally, spiritually, physically and mentally able to fit into the society and the labour market. Staff development provides growth in staff academic career and improved university organization. In other words, it assists in the promotion of academic staff from one level to another and encourages hard work amongst them. During the period of staff development, academic staff are privileged to be trained and retained. These outputs measure the extent to which university organizations achieve their goals, which is dependent on the acquisition of new skills, knowledge and experiences attributable to staff development programmes. One of the major problems confronting employers worldwide is the issue of poor productivity (Etudor, 2001). It is against this backdrop that this study was undertaken.

\subsection{Statement of the Problem}

One of the major problems confronting employers worldwide is the issue of low productivity (Etudor, 2001). This has been attributed to lack of the skills required to increase productivity. Most of the people employed are either 
unskilled, semi-skilled or non-professional workers. It takes time for these categories of people to acquire the necessary skills for increased output. In most universities in south-south of Nigeria, academic staff are not adequately productive due to inadequate or non-availability of staff development programmes. Academic staff cannot live up to expectation particularly in preparation of lessons, teaching their students, evaluating their performance and conducting research.

This problem has been of concern to stakeholders in the university system. Moreover, some graduates that are turned out from these universities can hardly write memo or communicate effectively and meaningfully. They cannot defend their qualifications or degrees. On the part of teachers (Staff) they have very low morale, poor attitudes particularly towards embracing opportunities such as in-service training, ICT training, conferences, seminars and workshops. They lack academic staff sponsorship towards enhancing academic staff output. Many researchers like Nwiyi and Dominic, 2008, Collins, 2005 and Agah, 2002 have made frantic effort to address the problem of low output in state universities but their efforts have not yielded better results. It is against this backdrop that the researchers are investigating the extent to which staff development influences academic staff output in the state universities.

\subsection{Hypotheses}

1. In-service training does not significantly influence the output of academic staff in terms of research, teaching and community service.

2. Academic staff attendance of conferences does not significantly influence their output in terms of research, teaching and community service.

3. Academic staff attendance of workshops does not significantly influence their output in terms of research, teaching and community service.

\section{$2 \quad$ Methodology}

The population of the study comprised the 2,894 academic staff of the three state universities under study. The universities are Rivers State University of Science and Technology Port Harcourt, Cross River State University of Technology, Calabar and Delta State University, Abraka. The study area was South-South of Nigeria which covered Rivers State, Akwa Ibom State, Cross River State, Bayelsa State, Delta State and Edo State. Three assistant researchers were appointed to collect data from the respondents.

The ex-post facto survey design was adopted for the study. Simple random sampling was used to select the required sample for the study. The sample of the study was 409 academic staff. Data was collected using a questionnaires 
entitled, "Academic Staff Development and Academic Staff Output Questionnaire" (ASDASOQ).

The ASDASOQ comprised of 60 items split into two parts, A and B. Part A was design to elicit information on the gender, age, occupation and working experience of the respondents while part B elicited information on staff development and productivity. A second instrument was used to elicit information from students concerning academic staff output in the areas of research, teaching and community service. The validity of the instruments was ascertained by two experts in measurement and evaluation who confirmed the appropriateness of the items in the instrument. The reliability of the instruments was determined through a trial test using Cronbach alpha method. This yielded a reliability coefficient of 0.70 and 0.92 for the staff and student questionnaires respectively.

\section{$3 \quad$ Findings}

\subsection{Hypothesis 1}

To assess the level of in-service training in the area of research, the data obtained from respondents were categorized into low, average and high based on the mean. Those who scored below the mean were categorized as low, those who scored within the mean region were scored average, while those who scored above the mean were categorized as high. Based on this categorization, 209 perceived in-service training as low, 43 respondents perceived in-service training as average, while 150 respondents perceived it as high. The means and standard deviation of these categories were first computed and compared using the one way analysis of variance (Table 1).

Table 1: Influence of in-service training on research, teaching and community service

\begin{tabular}{lllll}
\hline Variables & Level of output & $\mathbf{n}$ & $\bar{x}$ & SD \\
\hline Research & Low & 209 & 22.43 & 3.70 \\
& Average & 43 & 22.12 & 3.37 \\
& High & 150 & 23.19 & 4.44 \\
Teaching & Total & 402 & 22.79 & 3.97 \\
& Low & 209 & 15.80 & 3.76 \\
& Average & 43 & 17.17 & 3.74 \\
& High & 150 & 17.87 & 3.31 \\
Community Service & Total & 402 & 15.42 & 3.72 \\
& Low & 209 & 22.19 & 3.72 \\
& Average & 43 & 23.67 & 3.22 \\
& High & 150 & 23.50 & 5.02 \\
& Total & 402 & 22.84 & 4.63 \\
\hline
\end{tabular}


The result presented in Table 1, shows that respondents who perceived staff inservice training as being high had higher mean output in terms of research $\left(\mathrm{x}_{1}=\right.$ $\left.22.43, \mathrm{x}_{2}=22.12, \mathrm{x}_{3}=23.19\right)$. Teaching $\left(\bar{x}_{1}=15.80,{ }^{\bar{x}_{2}}=17.17,{ }^{\bar{x}}=17.87\right)$. Community service $\left(\bar{x}_{1}=22.19, \bar{x}_{2}=23.67, \bar{x}_{3}=23.50\right)$.

Table 2: ANOVA in influence of staff in-service training on the level of output in research, teaching and community service

\begin{tabular}{|c|c|c|c|c|c|c|}
\hline Variables & $\begin{array}{l}\text { sources of } \\
\text { Variance }\end{array}$ & $\begin{array}{l}\text { sum of } \\
\text { square }\end{array}$ & $\begin{array}{l}\text { Degree of } \\
\text { freedom }\end{array}$ & Mean & $F$ & Sig \\
\hline \multirow[t]{3}{*}{ Research } & between & 1207.827 & 2 & 603.914 & 28.741 & 0.000 \\
\hline & $\begin{array}{l}\text { within } \\
\text { group }\end{array}$ & 8383.984 & 399 & 21.012 & & \\
\hline & Total & 9591.811 & 401 & & & \\
\hline \multirow[t]{3}{*}{ Teaching } & $\begin{array}{l}\text { between } \\
\text { group }\end{array}$ & 384.289 & 2 & 192.44 & 14.846 & 0.000 \\
\hline & $\begin{array}{l}\text { within } \\
\text { group }\end{array}$ & 5164.062 & 399 & 12.943 & & \\
\hline & Total & 5548.3551 & 401 & & & \\
\hline \multirow[t]{3}{*}{$\begin{array}{l}\text { Community } \\
\text { service }\end{array}$} & $\begin{array}{l}\text { between } \\
\text { group }\end{array}$ & 489.218 & 2 & 244.609 & 23.053 & 0.000 \\
\hline & $\begin{array}{l}\text { within } \\
\text { group }\end{array}$ & 4233.660 & 399 & 10.611 & & \\
\hline & Total & 4722.878 & 401 & & & \\
\hline
\end{tabular}

$\mathrm{P}<0.05, \mathrm{~F}_{2}, 399=3.02$

Analysis of the results presented in Table 2, shows that there is a significant influence of in-service training on output in terms of research, $(\mathrm{f}=1.688, \mathrm{P}<$ $0.05)$, teaching $(\mathrm{f}=14.846 ; \mathrm{P}<0.05)$ and community service $(23.053, \mathrm{P}<$ 0.05). The null hypothesis was rejected for these variables because the calculated f-ratios of $28.741,14.846$ and 23.053 were found to be greater than the critical f-ratio of 3.02 at the .05 level of significance respective degrees of freedom. This finding means that staff development in terms of in-service training significantly influences output in terms of research, teaching and community service.

\subsection{Hypothesis 2}

Academic staff attendance of conferences does not significantly influence their output in terms of research, teaching and community services. The findings on this hypothesis are shown in Tables 3 and 4. 
Table 3: Influence of academic staff attendance of conference on their level of output in terms of research, teaching and community service

\begin{tabular}{lllll}
\hline Variables & Level of output & $\mathbf{n}$ & $\bar{x}$ & SD \\
\hline Research & Low & 226 & 20.65 & 5.10 \\
& Average & 31 & 22.61 & 4.27 \\
& High & 145 & 24.42 & 3.66 \\
Teaching & Total & 402 & 22.6 & 4.89 \\
& Low & 226 & 22.61 & 3.74 \\
& Average & 31 & 17.10 & 3.42 \\
& High & 145 & 24.45 & 3.21 \\
Community Service & Total & 402 & 16.72 & 3.72 \\
& Low & 22.6 & 24.42 & 4.53 \\
& Average & 31 & 18.24 & 453 \\
& High & 145 & 23.60 & 4.91 \\
& Total & 402 & 22.84 & 4.63 \\
\hline
\end{tabular}

Observation of the result in Table 3, shows that those respondents who perceived staff attendance of academic conferences as high had high mean of output in terms of research $\left(\mathrm{x}_{1}=20.65, \mathrm{x}_{2}=15.70, \mathrm{x}_{2}=22.13\right)$. Teaching $\left(\bar{x}_{1}=\right.$ $\left.22.61, \mathrm{x}_{2}=17.10,{ }^{\bar{x}}=24.45\right)$. Community service $\left(\bar{x}_{1}=24.42, \bar{x}_{2}=18.24, \bar{x}_{3}=\right.$ 23.60).

Table 4: ANOVA in influence of academic staff conference attendance on the level of output in terms of research, teaching and community service

\begin{tabular}{|c|c|c|c|c|c|c|}
\hline Variables & $\begin{array}{l}\text { sources of } \\
\text { Variance }\end{array}$ & $\begin{array}{l}\text { sum of } \\
\text { square }\end{array}$ & $\begin{array}{l}\text { Degree of } \\
\text { freedom }\end{array}$ & Mean & $F$ & Sig \\
\hline \multirow[t]{3}{*}{ Research } & $\begin{array}{l}\text { between } \\
\text { group }\end{array}$ & 44.533 & 2 & 632.718 & 30.320 & 0.000 \\
\hline & $\begin{array}{l}\text { within } \\
\text { group }\end{array}$ & 6279.330 & 399 & 20.868 & & \\
\hline & Total & 0323.863 & 401 & & & \\
\hline \multirow[t]{3}{*}{ Teaching } & $\begin{array}{l}\text { between } \\
\text { group }\end{array}$ & 575.550 & 2 & 287.775 & 23.090 & 0.000 \\
\hline & $\begin{array}{l}\text { within } \\
\text { group }\end{array}$ & 4972.801 & 399 & 12.463 & & \\
\hline & Total & 5548.351 & 401 & & & \\
\hline \multirow[t]{3}{*}{$\begin{array}{l}\text { Community } \\
\text { service }\end{array}$} & $\begin{array}{l}\text { between } \\
\text { group }\end{array}$ & 27.7234 & 2 & 139.367 & 6.671 & 0.000 \\
\hline & $\begin{array}{l}\text { within } \\
\text { group }\end{array}$ & 8335.756 & 399 & 20.892 & & \\
\hline & Total & 8614.490 & 401 & & & \\
\hline
\end{tabular}

$P<0.05, F_{2}, 399=3.02$ 
Analysis of the result presented in Table 4, shows that there is a significant influence of academic staff conference attendance on the level of output in terms of research, $(\mathrm{F}=30.320, \mathrm{P}<0.005)$, Teaching $(\mathrm{F}=23.090, \mathrm{P}<0.05)$ and community service $(\mathrm{F}-6.671, \mathrm{P}<0.05)$.

The null hypothesis was rejected because the calculated f-ratio of 30.320:23.090 and 6.671 were found to be greater than the critical f-ratio of 3.02 given .05 level of significance and respective degrees of freedom. This finding implies that staff development in terms of conference attendance significantly influences output in terms of research, teaching and community service.

\subsection{Hypothesis 3}

Academic staff attendance of workshops does not significantly influence their output in terms of research, teaching and community service. The findings on this hypothesis are shown in Tables 5 and 6.

Table 5: Influence of staff attendance of workshops and the level of output in terms of research, teaching and community service

\begin{tabular}{lllll}
\hline Variables & level of output & $\mathbf{n}$ & $\bar{x}$ & SD \\
\hline Research & Low & 206 & 21.73 & 3.75 \\
& Average & 98 & 22.43 & 3.06 \\
& High & 98 & 25.39 & 4.10 \\
& Total & 402 & 22.79 & 3.97 \\
& & & & \\
Teaching & Low & 206 & 15.45 & 3.79 \\
& Average & 98 & 17.39 & 3.26 \\
& High & 98 & 18.54 & 3.08 \\
& Total & 402 & 16.72 & 3.73 \\
Community Service & & & & \\
& Low & 206 & 21.55 & 4.48 \\
& Average & 98 & 22.74 & 4.07 \\
& High & 98 & 25.64 & 4.28 \\
& Total & 402 & 22.84 & 4.63 \\
\hline
\end{tabular}

Analysis of the result in Table 5, shows that those respondents who perceived staff attendance of workshops had higher mean attainment of output in terms of research, $\left(\mathrm{x}_{1}=25.39, \mathrm{x}_{2}=22.43, \bar{x}_{3}=21.73\right)$ teaching $\left(\bar{x}_{1}=18.54, \mathrm{x}_{2}=17.39\right.$, $\bar{x}=15.45)$ and community service $\left(\bar{x}_{1}=25.64, \bar{x}_{2}=22.74, \bar{x}_{3}=21.55\right)$ than those who perceived staff attendance of workshops as low or average. 
Table 6: ANOVA in influence of academic staff academic attendance of workshops on the level of output in terms of research, teaching and community service

\begin{tabular}{|c|c|c|c|c|c|c|}
\hline Variables & $\begin{array}{l}\text { sources of } \\
\text { Variance }\end{array}$ & $\begin{array}{l}\text { sum of } \\
\text { square }\end{array}$ & $\begin{array}{l}\text { Degree of } \\
\text { freedom }\end{array}$ & Mean & $F$ & Sig \\
\hline \multirow[t]{3}{*}{ Research } & $\begin{array}{l}\text { between } \\
\text { group }\end{array}$ & 940.282 & 2 & 452.141 & 33.288 & 0.000 \\
\hline & $\begin{array}{l}\text { within } \\
\text { group }\end{array}$ & 5419.581 & 399 & 13583 & & \\
\hline & Total & 6323.863 & 401 & & & \\
\hline \multirow[t]{3}{*}{ Teaching } & $\begin{array}{l}\text { between } \\
\text { group }\end{array}$ & 653.642 & 2 & 326.821 & 26.641 & 0.000 \\
\hline & $\begin{array}{l}\text { within } \\
\text { group }\end{array}$ & 4894.709 & 399 & 12.267 & & \\
\hline & Total & 5548.351 & 401 & & & \\
\hline \multirow[t]{3}{*}{$\begin{array}{l}\text { Community } \\
\text { service }\end{array}$} & $\begin{array}{l}\text { between } \\
\text { group }\end{array}$ & 1114.35 & 2 & 557.177 & 29.641 & 0.000 \\
\hline & $\begin{array}{l}\text { within } \\
\text { group }\end{array}$ & 7500.173 & 399 & 18.797 & & \\
\hline & Total & 8614.490 & 401 & & & \\
\hline
\end{tabular}

$\mathrm{P}<0.05, \mathrm{~F}_{2}, 399=3.02$

Observations of the result presented in table 6 shows that there is a significant influence of academic staff attendance of workshops on the level of output in terms of research $(\mathrm{F}=33.288 ; \mathrm{P}<.05)$ Teaching $(\mathrm{F}=26.641 ; \mathrm{P}<.05)$, community service $(\mathrm{F}=29.641 ; \mathrm{P}<.05)$ The null hypothesis was rejected because the calculated f-ratio of $33.288,26.641 ; 29.641$ were found to be greater than the critical F-ratio of 3.02 given .05 level of significance and with 2 and 399 degree of freedom. This findings implies that staff development in terms of attendance of workshops significantly influences output in terms of research, teaching and community.

\section{Discussion, Conclusion and Recommendations}

The findings of this study revealed that there exists a significant influence of inservice training on academic staff output in universities. This implies that the output of those who are enrolled on in-service training is more impressive in the areas of research, teaching and rendering of services to the community. This result is in agreement with the studies of Etudor (2001), Huang (2001) and Collins (2003) whose research results on the influence of in-service training on workers output was found to be significant. In other words in-service training has a significant influence on staff output. The study is also in agreement with 
Inyang and Akpama (2002) who affirmed that in-service training is a necessary pre-requisite for organizational staff to achieve the goal of high output.

The findings from the test of the second hypothesis showed that there exists a significant influence of staff output through conference attendance on their development in the areas of research, teaching and community service. The result of this study is in consonance with the findings of the research work of Monahan (1996), Bateman and Organ (2003) and Locke (2004) whose studies on staff attendance at conferences and their output found a significant relationship between conference attendance and academic staffs' productivity.

In addition, the findings of this study corroborates with Okeke (2000) who stated clearly that the environment of staff development through conferences is very imperative and has become noticeably with the challenging development in the society with the rapid rate of technological changes, training received by workers a few years ago is inadequate to meet the challenges of today's school system. Hence, according to him, academic staff need to attend conferences and seminars regularly to update their knowledge, expand their capacity to develop the skills and knowledge need for the new challenges. Above all, nonattendance of conferences often resulted in high rate of staff attrition, mediocrity, stagnation of staff growth and development.

The findings from the test of hypothesis three indicate that there exists a significant influence of staff attendance of workshops on their development through output from research, teaching and community service. Attendance of workshops has an impact on staff output in that it is an indicator for staff promotion, growth and development in the university system. In support of this contention, Sergiovanni and Elliott (2000), Watton (2005) and Kpela (2005) affirmed that workshop organization and attendance has a significant influence on staff output. According to them workshops are an important indices for staff development and they are used as an aspect of staff development programmes. They further maintained that the use of workshops is for the professional growth and development of staff.

Based on the findings of this study, the researchers concluded that in-service training given to academic staff influence and enhanced their output. This output is seen in the areas of research, teaching and community service. Similarly, when staff are exposed to the opportunity of attending conferences and workshops it will enhance their output and contribute tremendously to their professional growth and development. They are likely to acquire more knowledge and skills and the capacity to face challenges as the need arises. Therefore, based on the foregoing discussion, the following recommendations are made: 1) Government, in collaboration with educational stakeholders, should provide adequate staff development policies and programmes for academic staff in the educational management process; and 2) There is need for 
adequate provision of funds for staff development programmes so as to motivate them to put in their best for increased output in the university system.

\section{References}

Agah, I. E. (2002). Principal's managerial techniques and work performance of staff in Ahoada-East Senatorial district. Port Harcourt: Unpublished master's thesis. University Port Harcourt.

Babalola, J.B. (2009). Education that can raise Productivity in Nigeria. Being a Faculty Lecture delivered in the Faculty of Education, University of Ilorin, Nigeria.

Bateman, T. S \& Organ, O. W. (2003). Job satisfaction and the good soldier: The relationship between employee and citizenship. Academic of Management Journal, 26, 587- 595.

Boyel, V. (2004). School Context: Bridge or Barrier for Change. Austin: South West Educational Development Laboratory.

Collins, C. (2003). Enhancing SMTE business performance through the interest of e-learning platforms. Education and Training. 45, (8/9), 483-494.

Collins, U. (2005). ICT Training and Teachers. Port Harcourt: Immaculate Publishers.

Etudor, E. E. (2001) Human Resources Management Skill and Teachers Job Effectiveness in Akwa Ibom State unpublished Med Thesis, University of Calabar.

Huang T. C. (2001) The Relation of Training Practices and Organizational Performance in Small and Medium Size Enterprises Education and Training 43 (819), 437-444.

Inyang, B. J. \& Akpama, A. M. (2002) Personnel Management Practice in Nigeria. Calabar: Merb Business publisher.

Kpela, M. H. (2005) Undergraduate Teacher Trainees' Learning Style Performance: Implications for the 6-3-3-4 System. Port Harcourt: University Press.

Locke, E. A. (2004). The Nature and Causes of Job Satisfaction. In: D. D. Marvin (Ed) Handbook of Industrial and Organizational Psychology. Chicago: Rai McNally.

Monahan, T. C. (1996). Do Contemporary Incentives and Rewards Perpetuate Outdated Forms of Professional Development? Journal of Staff Development. 7 (1) 44-47.

Nkpodia, E. D. (2001). The of Educational Administration in Promotion of InService Teachers Education in Nigeria. Current Issues in Educational Management in Nigeria. Benin City: Ambic press. 
Nwiyi, G. Dominic, I. (2008) Contemporary Human Development. Port Harcourt: Nee Era press.

Okebukola, P. (2005 Quality Assurance in the Nigeria University System a key note address presented at the 2005 Fellowship Seminar Award of the Curriculum Organization of Nigeria held at Bauchi Road campus, university of Jos, Nigeria.

Okeke, B. S. (2000). A Handbook on Educational Administration. Owerri: New African Publishers.

Sergiovanni, T. J. \& Elliot, D. Z. (2000). Education and Organizational Leadership in Elementary Schools. New Jersey: Prince Hall.

Walton, D. (2005) Effective Secondary Classroom Practice. Washington D. C: Government Printing Press. 